\title{
REKAPITULASI DATA PRODUKSI IKAN PADA UNIT PELAKSANA TEKNIS TEMPAT PELELANGAN IKAN ( UPT TPI ) BERBASIS PYTHON DAN MYSQL
}

\author{
Honainah ${ }^{1)}$ \\ ${ }^{1)}$ STT NURUL JADID \\ e-mail: naina.aja@gmail.com ${ }^{1)}$
}

\begin{abstract}
Abstrak
Pengolahan data yang berbasis komputer telah berkembang sehingga banyak organisasi, sekolah, dan instansi memanfaatkan teknologi informasi dalam menunjang efektifitas dan efisiensi kerja. Unit Pelaksana Teknis Tempat Pelelangan Ikan (UPT TPI) salah satu bentuk usaha yang mempunyai tugas melaksanakan sebagian kegiatan teknis operasional dan teknis penunjang pengembangan dalam bidang yang ditangani. Dimana sistem yang ada, saat ini pada proses rekapitulasi data produksi ikan masih kurang efisien karena menggunakan aplikasi Ms Excel yang masih sering menyebabkan tumpang tindih data, proses rekap data lama dan laporan tidak sesuai yang diakibatkan belum adanya sistem database yang menyimpan dan mengarsip setiap laporan rekapitulasi. Oleh karena itu sistem baru sangat dibutuhkan yang bertujuan untuk mengatasi masalah tersebut. Metode Penelitian yang digunakan dalam Penelitian ini adalah observasi, wawancara dan studi literatur sedangkan metode pegembangan sistem yang digunakan adalah waterfall yang memiliki tahapan analisis, desain, coding, testing dan maintenance. Hasil dari penelitian ini adalah sistem baru yang dibuat terbkti mampu mengatasi permasalahan rekapitulasi , mulai dari data kapal, data ikan yang ditimbang dan penyediaan laporan rekapitulasi tiap bulan dan tahun.
\end{abstract}

Kata Kunci: Rekapitulasi, Produksi, dan Python

\begin{abstract}
Computer-based data processing has developed so many organizations, schools, and institutions use information technology in supporting the effectiveness and efficiency of work. Technical Implementation Unit of Fish Auction Sites ( UPT TPI) one form of business which has the task of carrying out most of the technical activities of operational and technical support in the development of the treated area. Where the existing system, currently in the process of data summary fish production is still less efficient because it uses the application Ms Excel is still often leads to overlapping of data, process data recap the old and the report does not match and the absence of database systems that store and archive any summary report. Therefore, a new system is needed that aims to address the problem. Research methods used in this study is observation, interview and literature studies pegembangan system while the method used is the waterfall that has stages of analysis, design, coding, testing and maintenance. Results from this study is a new system able to overcome the problems created terbkti recapitulation, ranging from ship data, the data of fish are weighed and the provision of summary report each month and year.
\end{abstract}

Keywords: recapitulation, Production, and Python

\section{PENDAHULUAN}

Kemajuan teknologi saat ini semakin berkembang pesat, khususnya teknologi yang berbasis komputer. Kemajuan dibidang teknologi tersebut menyebabkan banyaknya bidang usaha yang ikut memajukan usahanya ke dalam teknologi komputer dengan harapan dapat membantu para pengusaha untuk memprediksi keadaan atau kebutuhan masa depan sehingga para pengusaha dapat memajukan usahanya. Dengan adanya kepentingan tersebut maka diperlukan sistem berkualitas tinggi dan tepat waktu.

Unit Pelaksana Teknis Tempat Pelelangan Ikan (UPT TPI) merupakan salah satu bentuk usaha yang mempunyai tugas melaksanakan sebagian kegiatan teknis operasional dan teknis penunjang pengembangan dalam bidang yang ditangani. Untuk itu dibutuhkan penanganan yang lebih baik terhadap sistem-sistem yang ada, termasuk sistem rekapitulasi data produksi ikan.

UPT TPI Mayangan merupakan salah satu Unit Pelaksana Teknis Dinas Kelautan dan Perikanan Kota Probolinggo yang memiliki kompleksitas tinggi salah satunya diharuskan 
memberikan informasi hasil rekapitulasi data produksi ikan ke Dinas Kelautan dan Perikanan Kota Probolinggo dengan tingkat keakuratan harus tinggi. Akan tetapi sistem rekapitulasi yang sedang berjalan saat ini masih dapat dikatakan belum efisien. Data kapal masuk yang melakukan pembongkaran ikan dan data ikan yang ditimbang dicatat dalam sebuah nota, kemudian data-data tersebut dijumlahkan berdasarkan jenis masingmasing. Input dan output data dilakukan satu persatu dengan menggunakan Ms Exel. Pastinya semua proses tersebut membutuhkan waktu yang relatif lama dan energi yang lebih besar untuk mencapai keakuratan laporan yang diinginkan. Dari sistem yang berjalan di UPT TPI Mayangan pembuatan laporan menjadi tidak tepat waktu.

Dilihat dari permasalahan yang dijabarkan di atas dirasa perlu untuk membuat sistem baru yang dapat mengatasi berbagai permasalahan yang ada dengan judul " Rekapitulasi data produksi ikan pada Unit Pelaksana Teknis Tempat Pelelangan Ikan (UPT TPI) berbasis Python dan Mysql" sehingga dapat mempermudah instansi dalam melakukan proses input dengan tepat waktu dan tingkat keakuratan yang lebih tinggi.

\section{LANDASAN TEORI}

\subsection{Konsep Dasar Sistem Informasi 2.1.1 Pengertian Sistem}

Suatu sistem merupakan suatu jaringan kerja dari prosedur-prosedur yang saling berhubungan, berkumpul bersama-sama untuk melakukan suatu kegiatan atau menyelesaikan suatu sasaran tertentu. (Al-Bahra Bin Ladjamudin [1].

Suatu sistem mempunyai karakteristik atau sifat-sifat tertentu yaitu [2] :

a) Bagian (Component).

b) Batas Sistem (Boundry).

c) Lingkungan Luar Sistem (Environment).

d) Penghubung Sistem (Interface).

e) Masukkan Sistem (Input).

f) Keluaran Sistem (Output).

g) Pengolah Sistem (Process).

h) Sasaran Sistem (Objective).

\subsubsection{Pengertian Sistem Informasi}

Sistem informasi adalah suatu sistem di dalam suatu organisasi yang mempertemukan kebutuhan pengolahan transaksi harian, mendukung operasi, bersifat manajerial dan kegiatan strategi dari suatu organisasi dan menyediakan pihak luar tertentu dengan laporanlaporan yang diperlukan.

Dari pengertian diatas, sistem informasi dapat didefinisikan pula sebagai suatu kesatuan dari berbagai bagian atau elemen-elemen atau subsistem-subsistem yang saling berkaitan dan berinteraksi satu sama lainnya untuk mencapai suatu tujuan tertentu.

\subsection{Pengertian Rekapitulasi}

Menurut Mintorogo dan Sedarmayanti (1992: 41) Rekapitulasi adalah suatu kegiatan meringkaskan data sehingga menjadi lebih berguna bentuk, susunan, sifat atau isinya dengan bantuan tenaga tangan atau bantuan suatu peralatan dan mengikuti rangkaian langkah, rumus, atau pola tertentu.

\subsection{Pengertian Produksi}

Produksi adalah semua kegiatan dalam menciptakan atau menambah kegunaan barang atau jasa, dimana untuk kegiatan tersebut diperlukan faktor-faktor produksi [3]

\subsection{Rekayasa Perangkat Lunak}

Perangkat lunak adalah instruksi (program komputer) yang bila dieksekusi dapat menjalankan fungsi tertentu, struktur data yang dapat membuat program memanipulasi informasi, dokumen yang menjelaskan program[4]. Menurut IEEE (Institute of Electrical and Electronics Engineers), perangakat lunak adalah program komputer, prosedur, aturan dan dokumentasi yang berkaitan serta data, yang bertalian dengan operasi suatu sistem komputer.

Rekayasa perangkat lunak adalah pengembangan dan penggunaan prinsip pengengembangan suara untuk memperoleh perangkat lunak secara ekonomis, reliabel, dan bekerja secara efisien pada mesin nyata[5]. Rekayasa perangkat lunak juga dapat didefinisikan secara lebih komprehensif yaitu aplikasi dari sebuah pendekatan kantifiabel, disiplin, dan sistematis kepada pengembangan, operasi, dan pemeliharaan perangkat lunak; yaitu aplikasi dari rekayasa perangkat lunak. Rekayasa perangkat lunak juga dapat berarti studi atau disiplin ilmu tentang hal tersebut[4].

\subsection{Pengembangan Sistem}

Pengembangan sistem (Systems Development) dapat berarti menyusun suatu sistem yang baru untuk menggantikan sistem yang lama secara keseluruhan atau memperbaiki sistem yang telah ada [6]

Tahapan Waterfall (air terjun) dalam model 


\section{SYSTEMIC}

Vol. 02, No. 01, Agustus 2016, 33-38

ini disusun bertingkat, setian tahap dalam model ini dilakukan berurutan, dmna output dari setiap tahap merupakan input bagi tahap berikutnya. Pada metode ini terdapat 5 tahapan untuk mengembangkan suatu perangkat lunak. Kelima tahapan itu tersusun dari atas kebawah, diantaranya : Analysis, Design, Coding,

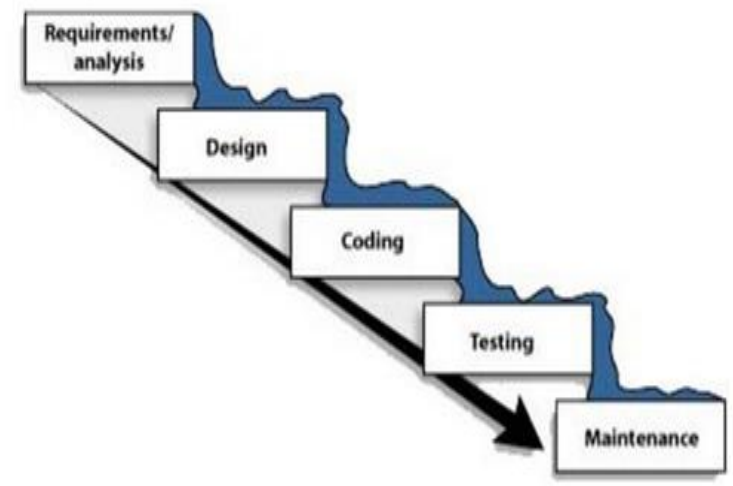

Gambar 1 Metode waterfall

Sumber : Roy Sari Milda Siregar

a) Analysis

Mempelajari sistem yang ada dan menganalisis terhadap permasalah han untuk mengetahui kebutuhan serangkaian dan teknik yang diperlukan serta menemukan batasan-batasan sistem. Sehingga dapat menentukan cara yang paling efektif dalam menyelesaikan dan akan memberikan solusi yang diperlukan serta manfaat yang akan diperoleh.

b) Design

Merupakan tahapan analisis dalam kaitan mencari atau merumuskan alternatifalternatif pemecahan maslah. Setelah menganalisis masalah, selanjutnya dilakukan perancangan sistem yang telah ditetapkan menggunakan Use Case Diagram, Activity Diagram, Class diagram, Sequence Diagram.

c) Coding

Tahap pembuatan kode merupakan tahap dimana membuat source code yang diperlukan untuk sistem aplikasi potensi pelanggaran pemilu berbasis web.

d) Testing

Proses uji coba yang dilakukan untuk mengetahui keberhasilan program yang kita buat, yang nantinya akan diimplementasikan barupa aplikasi program (software), guna mengetahui apakah system maupun aplikasi yang dibangun sudah lanyak untuk dioprasikan. Jika masih terdapat kesalahan pada tahapan ini dilakuakan perbaikan-perbaikan guna menyempurnakan sistem yang telah dirancang.

e) Maintenance

Pemeliharaan program merupakan tahap dimana program yang telah dibuat diterapkan atau menginstal software yang telah selesai dibuat dan di ujikan oleh petugas kepada pengguna. Pada saat melakukan pengujian, petugas (user) harus benar-benar memahami program yang telahdibuat.

\subsection{Konsep Dasar Sistem Rekapitulasi Data Produksi Ikan}

Konsep dasar penggunaan sistem rekapitulasi data produksi ikan adalah sebagai berikut:

a) Merekam data kapal masuk

b) Merekam data ikan yang ditimbang

c) Memproses Rekapitulasi produksi ikan

d) Pembuatan Laporan Rekapitulasi produksi ikan

\section{RANCANGAN SISTEM}

Berdasarkan hasil observasi yang telah dilakukan, diperoleh data kapal masuk dan data ikan yang ditimbang, maka selanjutnya perlu dirumuskan hubungan antar data tersebut sehingga membentuk suatu hubungan sistematik untuk mencapai tujuan sistem. Dalam membentuk hubungan sistem yang baik perlu dilakukan analisa dan sistem terlebih dahulu.

Menurut Adi Nugroho (2010:6), "UML (Unified Modeling Language) adalah bahasa pemodelan untuk sistem atau perangkat lunak yang berparadigma (berorientasi objek)". Pemodelan (modeling) sesungguhnya digunakan untuk penyederhanaan permasalahanpermasalahan yang kompleks sedemikian rupa sehingga lebih mudah dipelajari dan dipahami [7].

Dalam sistem ini Pemodelan dilakukan dengan beberapa tahapan yaitu pembuatan Use Case Diagram, Activity Diagram, Sequence Diagram dan Class Diagram serta dilengkapi dengan desain program agar desain dapat lebih mudah dipahami secara detail dan mudah dikelompokkan.

\subsection{Use Case Diagram}

Use Case Diagram merupakan inti fungsional koheren yang diekspresikan sebagai transaksi-transaksi yang terjadi antara actor dan system. Dalam proses rekapitulasi data produksi 
ikan dapat ditampilkan pada use case diagram berikut :

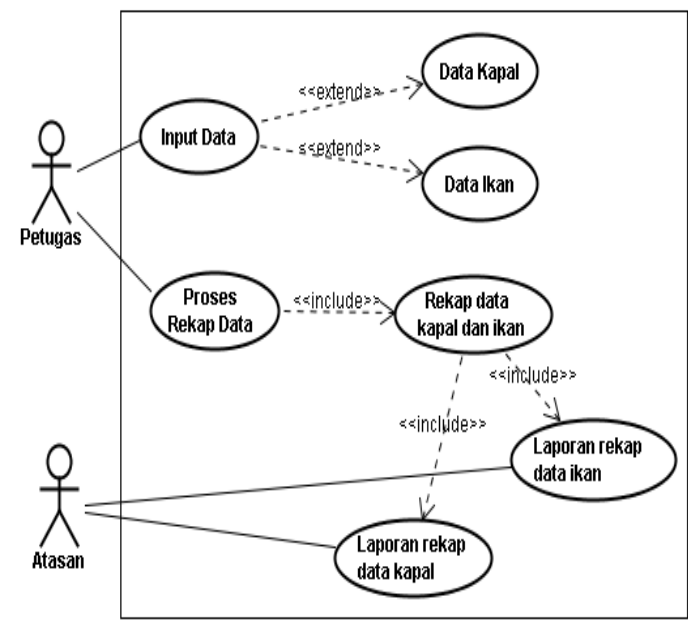

Gambar 2 Use Case diagram sistem informasi rekapitulasi data produksi ikan

Keterangan :

a) Petugas melakukan input data yaitu data kapal dan data ikan.

b) Kemudian petugas melakukan proses rekap data kapal dan data ikan.

c) Dari proses rekap data tersebut petugas membuat laporan bulanan data kapal dan data ikan.

d) Setelah itu hasil laporan diserahkan kepada atasan .

\subsection{Activity Diagram}

Secara grafis digunakan untuk menggambarkan rangkaian aliran aktivitas baik proses bisnis maupun use case. Activity diagram dapat juga digunakan untuk memodelkan action yang akan dilakukan saat sebuah operasi dieksekusi, dan memodelkan hasil dari action tersebut. Dalam proses rekapitulasi data produksi ikan dapat ditampilkan pada activity diagram berikut :

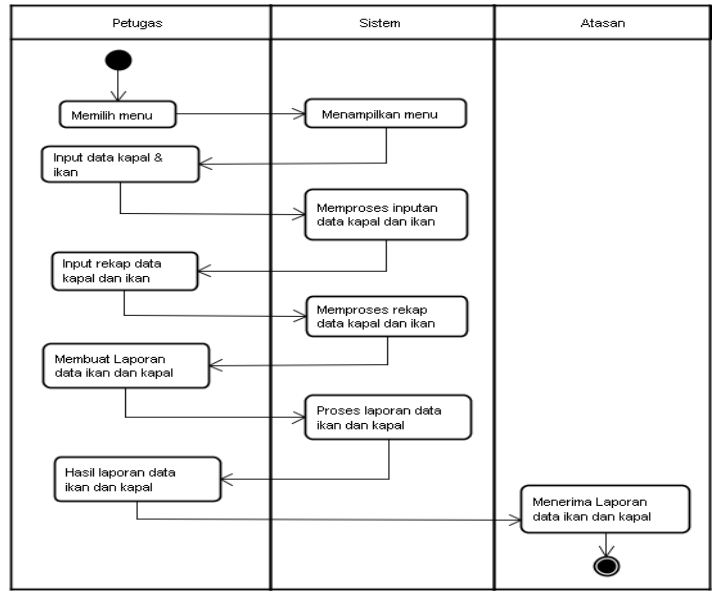

Gambar 3. Activity diagram rekapitulasi data produksi ikan

Keterangan :

a) Petugas memilih menu data produksi ikan kemudian sistem menampilkan menu tersebut.

b) Petugas melakukan input data kapal dan data ikan yang akan diproses oleh sistem.

c) Selanjutnya petugas melakukan rekap data kapal dan ikan kemudian sistem memproses rekap data tersebut.

d) Setelah itu petugas membuat laporan dari kedua data rekap tersebut dan hasilnya diserahkan kepada atasan.

\subsection{Squence Diagram}

Secara grafis menggambarkan bagaimana objek berinteraksi dengan satu sama lain melalui pesan pada sekuensi sebuah use case atau operasi. Dalam proses rekapitulasi data produksi ikan dapat ditampilkan pada use case diagram berikut:

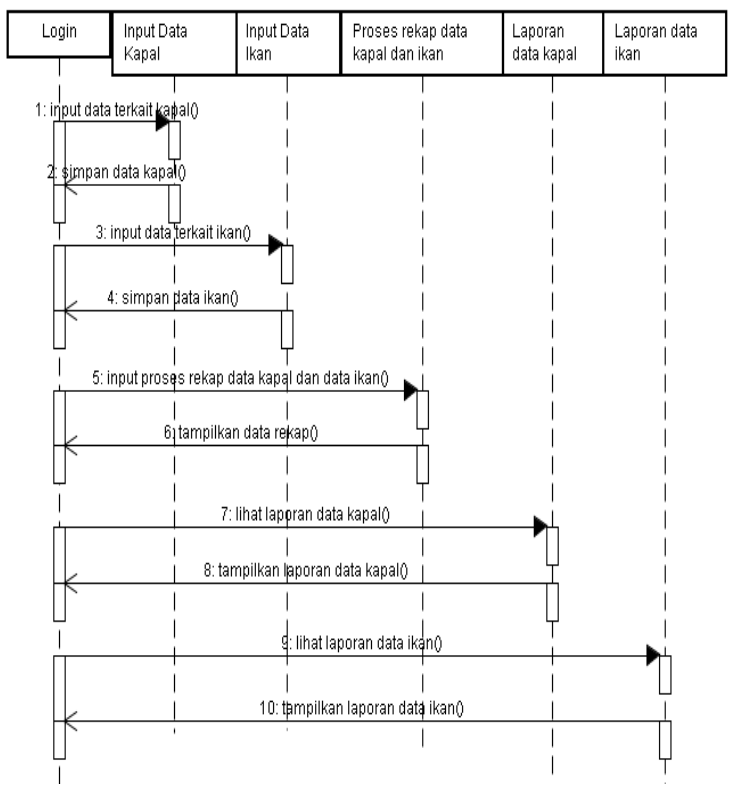

Gambar 4. Squence diagram sistem informasi rekapitulasi data produksi ikan

Keterangan :

a) Petugas melakukan login untuk masuk ke menu utama dan melakukan input data kapal dan ikan kemudian data tersebut akan tersimpan di database.

b) Petugas melakukan input rekap data kapal dan ikan, dan akan diproses oleh sistem kemudian data yang sudah tersimpan tersebut akan ditampilkan.

c) Untuk membuat laporan data rekap kapal dan ikan, petugas harus mencari data yang sudah 


\section{SYSTEMIC}

Vol. 02, No. 01, Agustus 2016, 33-38

tersimpan didatabase kemudian data yang sudah tersimpan tersebut akan ditampilkan.

\subsection{Class Diagram}

Menggambarkan struktur object system. Diagram ini menunjukkan class object yang menyusun sistem dan juga hubungan antara class object tersebut. Dalam proses rekapitulasi data produksi ikan dapat ditampilkan pada use case diagram berikut:

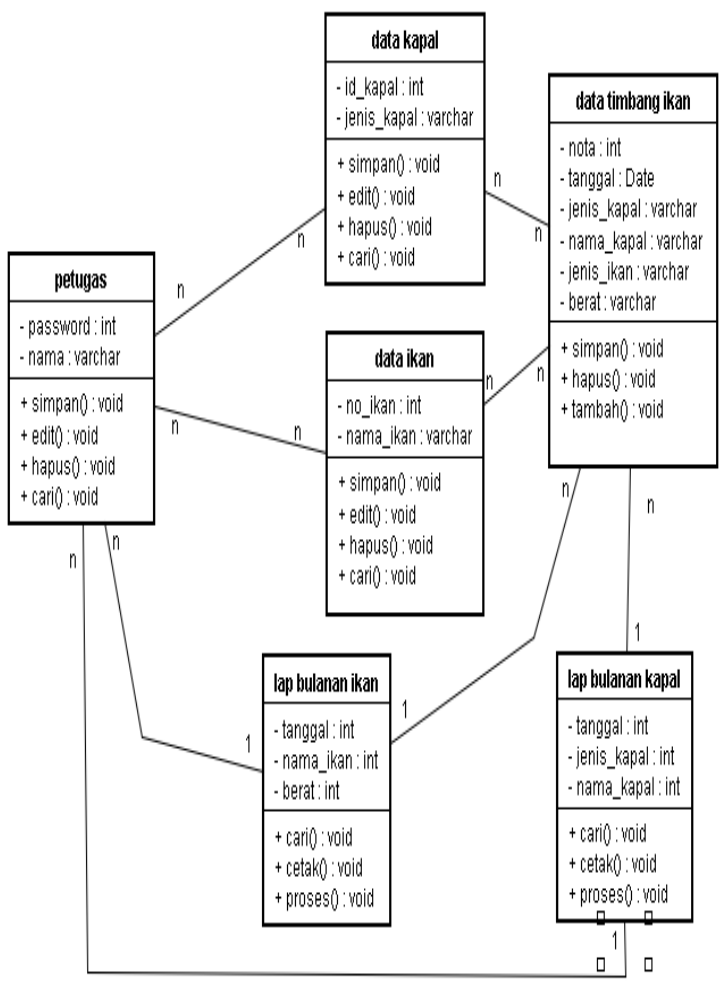

Gambar 5. Class diagram sistem informasi rekapitulasi data produksi ikan

Keterangan :

a) Class/table petugas ber-agregasi dengan tabel data kapal dan data ikan alasannya karena data kapal dan data ikan tidak bisa menginput sendiri tanpa adanya petugas. Banyak petugas bisa menginput data kapal dan data ikan jadi many to many

b) Class/table detail timbang tidak bisa berdiri sendiri tanpa adanya data kapal dan data ikan jadi many to many.

c) Class/table laporan bulanan data kapal dan data ikan tidak dapat berdiri sendiri tanpa adanya class detail timbang jadi many to one.

\section{HASIL DAN PEMBAHASAN}

Sistem Informasi Rekapitulasi Data Produksi Ikan ini dibuat untuk melengkapi sistem yang sudah ada di UPT TPI Mayangan Kota Probolinggo. dengan kata lain program aplikasi ini dibuat sebagai bahan pertimbangan bagi para manajemen dalam mengambil keputusan untuk menyelesaikan permasalahan Rekapitulasi Data Produksi Ikan pada UPT TPI Mayangan Kota Probolinggo.

Setelah tahapan perancangan selasai dibuat langkah selanjutnya adalah mengimplementasikan dalam bentuk koding pemrograman Python 2.5dan Mysql. Berikut alur program Rekapitulasi data produksi ikan pada UPT TPI Mayangan Kota Probolinggo :

a) Input dan Cari Data Kapal

Pencarian data ini digunakan untuk mencari informasi yang sedang dibutuhkan petugas untuk mencetak laporan data kapal. secara detail ditampilkan pada gambar 7

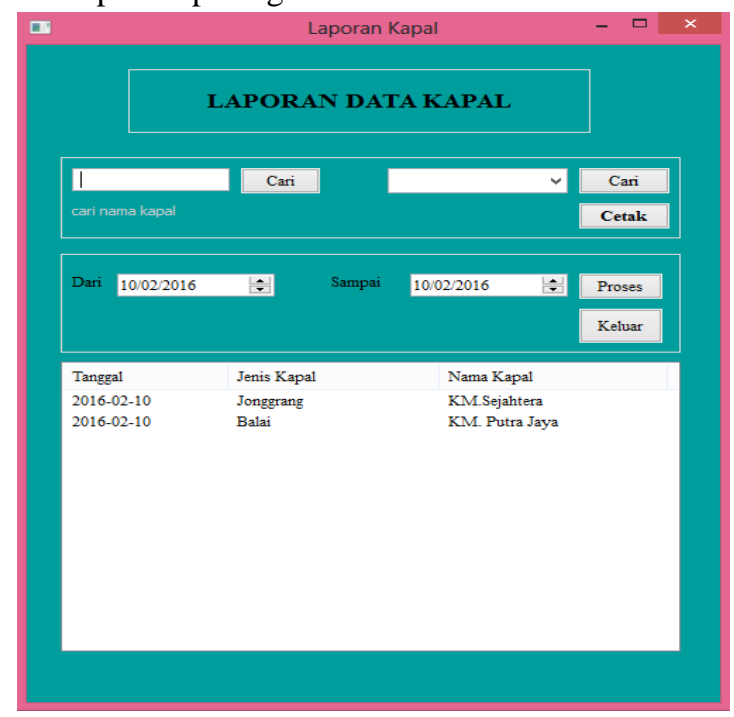

Gambar 7. Input Data Kapal

b) Input Data Ikan yang Ditimbang

Berikut adalah tampilan data ikan yang akan disimpan menurut tabel masing-masing, secara detail ditampilkan pada gambar 6 .

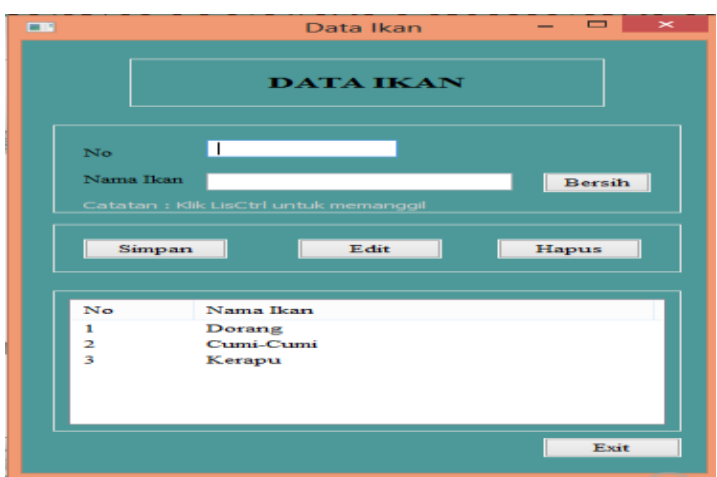


Gambar 8. Input data ikan yang ditimbang

c) Proses Rekapitulasi

Form ini digunakan untuk merekap data kapal dan data ikan, secara detail ditampilkan pada gambar 9.

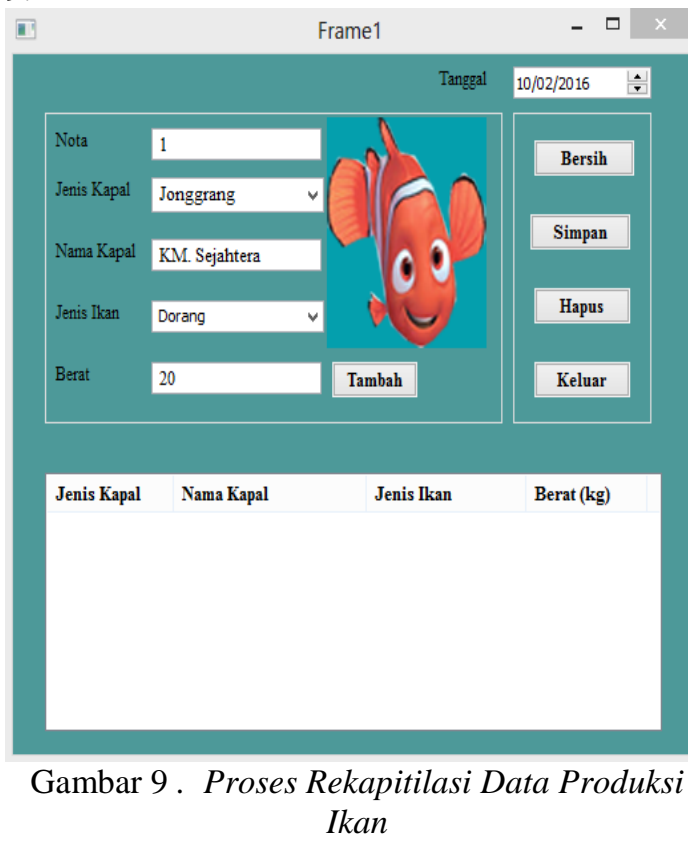

d) Laporan

Dalam form ini berisi Laporan data produksi ikan yang ada di UPT TPI Mayangan Kota Probolinggo,

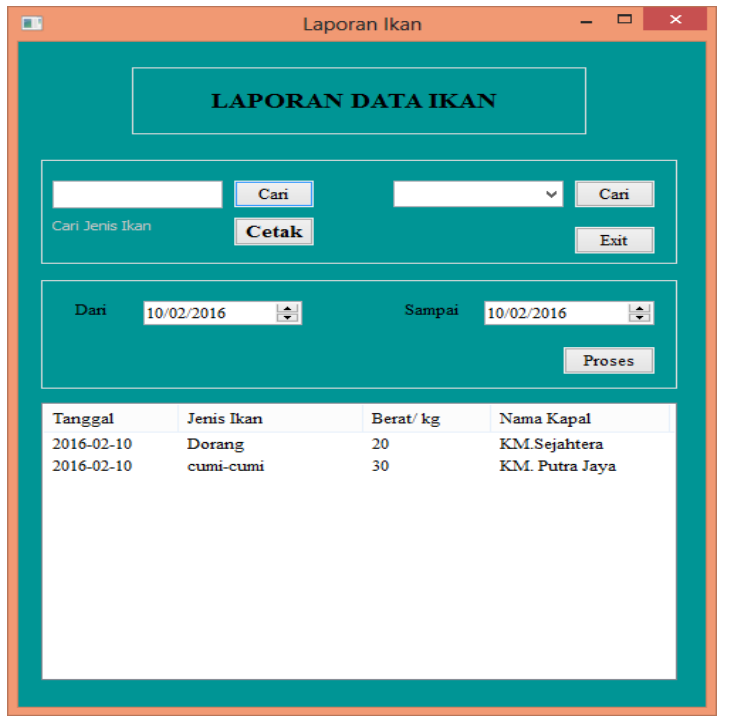

Gambar 10. Input data ikan yang ditimbang

\section{KESIMPULAN}

Berdasarkan analisa dan pembahasan dan pengujian sistem yang telah dilakukan dapat dihasilakan kesimpulan yang berkaitan dengan Sistem Rekapitulasi Data Produksi Ikan yang terbukti memiliki kelebihan tersendiri dalam Penggunaan sistem baru tersebut yaitu :

1. Sistem Informasi Rekapitulasi Data Produksi Ikan ini mampu mempermudah manajemen dalam rses input data kapal dan data ikan yang ditimbang.

2. Proses Rekapitulasi data Produksi ikan ini terbukti lebih akurat dan tidak memerlukan waktu yang lama.

3. Sistem Informasi Rekapitulasi Data Produksi Ikan ini menyediakan laporan yang dapat membatu pihak manajemen dalam pengambilan keputusan.

\section{DAFTAR PUSTAKA}

\section{Journal Article}

[1] Bin Ladjamudin, Al Bahra, Analisis dan Desain Sistem Informasi. Graha Ilmu, Tangerang : 2005

[2] HM, Jogianto, Analisis Dan Desain Sistem Informasi Pendekatan Terstruktur. Andi Offset. Yogyakarta : 1993

[3] Sumiarti, Murti et, al., Dasar-dasar Ekonomi Perusahaan, Edisi II, Penerbit Liberty, Yogyakarta, 1987.

[4] Haryanto Bambang, Sistem manajemen Basis Data, Informatika Bandung: 2004

[5] Jogiyanto HM, Analisis dan Desain Sistem Informasi : Pendekatan Terstruktur, Teori dan Praktek Aplikasi Bisnis, ANDI offset Yogyakarta: 2002

[6] Prof. Dr. Jogiyanto HM, M. A. (2005). Analisis \& Desain sistem informasi: pendekatan terstruktur teori dan praktik aplikasi bisnis. Andi offset. Yogyakarta: 2005

[7] Adi Nugroho. 2005. Analisis dan Perancangan Sistem Informasi Dengan Metodologi Berorientasi Objek. Informatika. Bandung

[8] Andy Dustman,Python and MySQL, Santa Clara : 2005

[9] Haryanto Bambang, Sistem manajemen Basis Data, Informatika Bandung: 2004 